\title{
METODE INPUTING DATA SISTEM INFORMASI PEMINJAMAN LABORATORIUM TEKNIK ELEKTRONIKA POLITEKNIK NEGERI MALANG
}

\author{
Imam Saukani ${ }^{1}$, Eko Pamuji ${ }^{2}$ \\ ${ }^{1}$ Jurusan Teknik Elektro, Politeknik Negeri Malang, Indonesia \\ mam_im@yahoo.com \\ (Artikel diterima: Oktober 2019, direvisi: September 2019, diterima untuk terbit: Januari 2020)
}

\begin{abstract}
This research report is a response to address the deficiencies in the lending system in laboratory instrumentation that is, the lending system is still done manually. The definition of a student loan to manually write the name, code and the number of tools that will be borrowed and submit the Student Identity Card (KTM) as collateral. Such borrowing procedure causes the system to become less effective ministry. In this Research Report, applications are made to the database in the laboratory identification using barcode technology. This application is created using ms access 2003 software for the database. The main function of this application is to simulate the process of borrowing and repayment instrumentation. The process was carried out through scanning the barcode on the card members (KTM) and instrumentation devices using barcode scanner. After the whole simulation process is complete, the data is stored in a database and can be printed to be used as evidence of borrowing. Other functions include, process data search've borrowed, instrumentation load, as well as lending report.
\end{abstract}

Keywords: Student Identity Card (KTM), database, scanning and barcode

\section{Pendahuluan}

Dengan semakin berkembangnya masyarakat maka informasi merupakan sarana yang penting saat ini. Informasi memaksa setiap insan baik individu ataupun kelompok, baik swasta maupunpemerintah, untuk memperhitungkan sistem informasi yang akan diterapkan supaya tetapkompetitif di era globalisasi. Dalam hal ini, penerapan strategi yang tepat memungkinkan setiapinstansi pemerintah untuk lebih meningkatkan pelayanan. Selain itu, kemajuan teknologi informasi yang semakin pesat, tetapi kurangnya pemanfaatan secara tepat.

Pada umumnya permasalahan yang dihadapi di Politeknik Negeri Malang adalah belum optimalnya pelayanan sistem peminjaman intrumentasi dimana dalam peminjaman masih secara manual sehingga terjadinya antrian pada waktu proses peminjaman. Prosedur peminjaman semacam ini menjadikan kurangnya efektifitas dalam sistem pelayanan.

Dalam perawatan instrumentasi bila masih manual akan kesulitan untuk mengetahui berapa jam alat itu terpakai dan terjadi kerusakan berapa kali.

Teknologi Auto-ID memudahkan manusia untuk melakukan proses identifikasi. Salah satu contoh teknologi ini adalah barcode. Kelebihan teknologi barcode yakni, scanner barcode dapat membaca informasi dengan kecepatan dan ketelitian yang jauh lebih tinggi daripada mengetikkan data secara manual, dengan tingkat ketelitian yang lebih tinggi menjadikan tingkat kesalahan lebih kecil.

Oleh karena itu kami memanfaatkan teknologi barcode untuk diaplikasikan ke dalam sistem informasi peminjaman dan perawatan intrumentasi di Laboratorium Telekomunikasi Politeknik Negeri Malang.

\section{Tinjauan Pustaka}

Sistem informasi adalah suatu sistem buatan manusia yang secara umum terdiri atas sekumpulan komponen berbasis komputer dan manual yang dibuat untuk menghimpun, menyimpan, dan mengelola data serta menyediakan informasi keluaran kepada para pemakai.
Menurut Sutedjo (2002), sistem adalah kumpulan elemen yang saling berhubungan satu sama lain yang membentuk satu kesatuan dalam usaha mencapai suatu tujuan. Informasi adalah hasil pemrosesan data yang diperoleh dari setiap elemen sistem tersebut menjadi bentuk yang mudah dipahami dan merupakan pengetahuan yang relevan yang dibutuhkan oleh orang untuk menambah pemahamannya terhadap faktafakta yang ada.

Teknologi Informasi merupakan bentuk teknologi masa kini yang menggambarkan kombinasi dari teknologi komputer (baik hardware maupun software) dengan teknologi telekomunikasi (seperti data, gambar, dan jaringan suara).

Management Information System (MIS) atau yang sering disebut Sistem Informasi Manajemen ialah sistem informasi yang menyediakan laporan beorientasi manajemen yang berdasar pada proses transaksi dan operasi pada suatu organisasi.

\section{A. Database}

Database adalah suatu kumpulan data-data yang disusun sedemikian rupa sehingga membentuk informasi yang sangat berguna. Database terbentuk dari sekelompok data-data yang memiliki jenis/sifat sama. Bahkan dalam perkembangannya, data-data tersebut dapat berbentuk berbagai macam data, misalkan dapat berupa program, lembaran-lembaran untuk entry (memasukkan) data, laporan-laporan. Kesemuanya itu dapat dikumpulkan menjadi satu yang disebut dengan database.

Data secara umum dapat dikatakan sebagai segala sesuatu yang dapat dikumpulkan. Tentu saja hal ini akan membuat segala sesuatu di dunia ini menjadi data, dan masing masing dapat dikumpulkan menurut jenisnya. Segala bentuk catatan mengenai data-data tersebut sebenarnya dapat dianggap sebagai database (tempat kumpulan data-data). Biasanya catatan dari data-data tersebut dilakukan dengan relatif sederhana dan dilakukan dengan cara manual (dicatat di atas lembaran-lembaran kertas, atau paling tidak diketik menggunakan program aplikasi tertentu). Setelah data-data tersebut dikumpulkan, biasanya diperlukan untuk pembuatan 
laporan, pengambilan keputusan atau segala sesuatu bentuk pengolahan yang berhubungan dengan data tersebut.

Jika data-data tersebut tercatat secara manual, maka segala bentuk pengolahan juga dilakukan secara manual (disusun, dihitung atau dibuat laporannya secara manual). Cara ini tentu saja membutuhkan ekstra tenaga dan waktu. Dan lebih sering lagi, diperlukan pengumpulan data-data yang sejenis secara berkali-kali dan dilakukan juga pengolahan dan pembuatan laporan secara berkali-kali pula. Bisa dibayangkan ini merupakan pekerjaan yang sangat membosankan.

Dari kenyataan tersebut, akan lebih mudah jika dibuat suatu sistem yang digunakan untuk menyimpan data-data tersebut secara lebih terorganisasi, dan dengan bantuan program-program aplikasi tertentu, data-data tersebut dapat diolah dan dibuat laporannya secara lebih cepat dan lebih mudah. Hal inilah yang menjadikan perlunya dibuat sistem database.

Meskipun sebenarnya tujuan dari database tersebut sama, yaitu lebih mempermudah dalam pengolahan data, namun caranya ada berbagai macam. Macam dari database tersebut dapat dilihat dari bentuk konfigurasi sistemnya atau dari bentuk/isi dari database tersebut.

Ada beberapa jenis dari database, mulai dari yang menggunakan text biasa, menggunakan exel, lotus, foxpro, dbase, paradoc, access, oracle, SQL dan banyak lagi. Masingmasing dapat berbeda dari sisi format datanya, fasilitas yang disediakan dan teknik pengolah databasenya (database engine).

\section{B. Microsoft Access 2003}

Section Microsoft Access (atau Microsoft Office Access) adalah sebuah program aplikasi basis data. Aplikasi ini merupakan anggota dari beberapa aplikasi Microsoft Office, selain tentunya Microsoft Word, Microsoft Excel, dan Microsoft PowerPoint. Aplikasi ini menggunakan mesin basis data Microsoft Jet Database Engine, dan juga menggunakan tampilan grafis yang intuitif sehingga memudahkan pengguna.

Database pada Access 2003 terdiri atas satu atau beb erapa tabel, query, form, report, page, makro, modul yang semuanya berhubungan atau saling terkait.

1. Tables, digunakan untuk menyimpan data.

2. Queries, digunakan untuk memanipulasi data.

3. Forms, digunakan untuk menampilkan data, mengisi data mengubah data yang ada di dalam tabel.

4. Report, digunakan untuk laporan, juga dapat dibuat dengan berisikan grafik atau label data.

5. Pages, digunakan untuk membuat halaman Web (page) berupa data access page yang dapat ditempatkan di server sistem jaringan intranet atau internet.

6. Macros, untuk mengotomatisasi perintah-perintah yang sering digunakan dalam mengolah data.

7. Modules, digunakan untuk perancangan berbagai modul aplikasi pengolahan database tingkat lanjut sesuai dengan kebutuhan. Module ini berisi kode Visual Basic for Applications yang ditulis untuk menangani even dalam Access 2003.

C. Mengenal Lembar Kerja MS. Access 2003

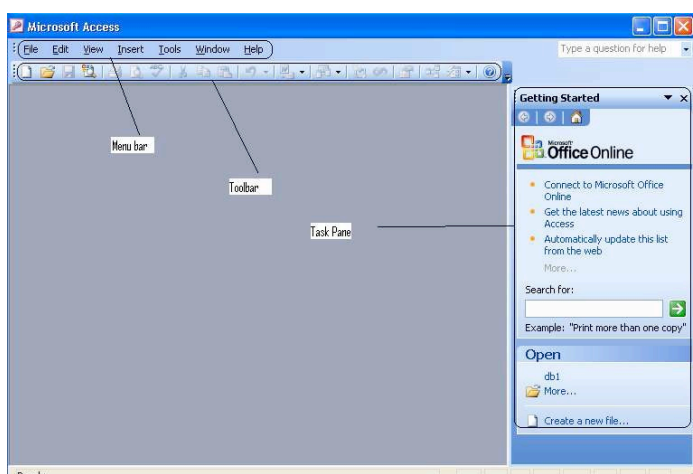

Gambar 1. Tampilan awal MS. Access 2003

Menu Bar, berisi item-item menu yang dapat digunakan untuk mengeloladatabase, tampilan item menu dapat berubah sesuai dengan object yangsedang di buka. Sewaktu pertama kali membuka MS. Access, maka item menuyang muncul adalah:

\section{File Édit Wiew Insert Iools window $\underline{H}$ elp Gambar 1. Menu Bar}

Bandingkan jika anda telah membuka sebuah tabel, maka tampilan item menusebagai berikut:

\section{File Editi Wiew Insert Format Records Iools Window Help}

Gambar 2. Menu Bar open table

Terlihat adanya penambaham item menu, yaitu menu format dan Records. Setiap menu mempunyai submenu-submenu tersendiri, sesuai denganfungsinya masing-masing. Baris Toolbar, merupakan kumpulan icon-icon yang sering digunakan dalammengelola database. Icon yang tampil pada toolbar juga ditentukan oleh objectapa yang sedang dibuka. Icon-icon yang ada pada toolbar sebenarnya sudah ada pada item menu, tapi dengan adanya toolbar ini lebih memudahkan andadalam melakukan suatu proses.

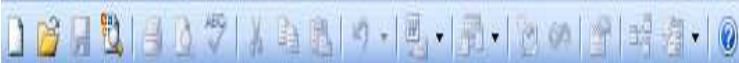 \\ Gambar 3. Baris Toolbar}

Task Panel, merupakan fasilitas yang berfungsi untuk mempermudah anda bekerja dengan MS. Access, baik untuk membuat database baru, membuka database yang lama, atau menggunakan fasilitas template.

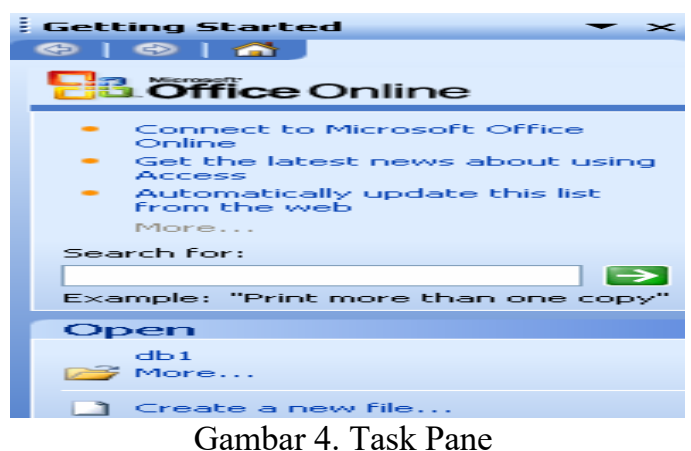

Lembar kerja MS. Access 2003 diaktifkan, maka muncul tampilan awal dari MS. Access 2003,seperti berikut : 


\section{Mengatur Regional Settings}

Mengatur Regional Settings setting merupakan bagian dari sistem operasi windows yang berfungsi untukmengelola aturan-aturan sistem penanggalan, waktu, mata uang dan penulisan angkadari suatu negara atau daerah (regional). Semua aturan yang di set pada bagian iniakan berpengaruh terhadap semua aplikasi office. Seperti MS. Word, MS. Excel, MS.Access yang anda gunakan ini, dan lain sebagainya. Agar format tanggal, waktu, simbol mata uang dan tata penulisan angka yang anda buat dengan MS. Klik Control Panel, sehingga tampil jendela berikut :

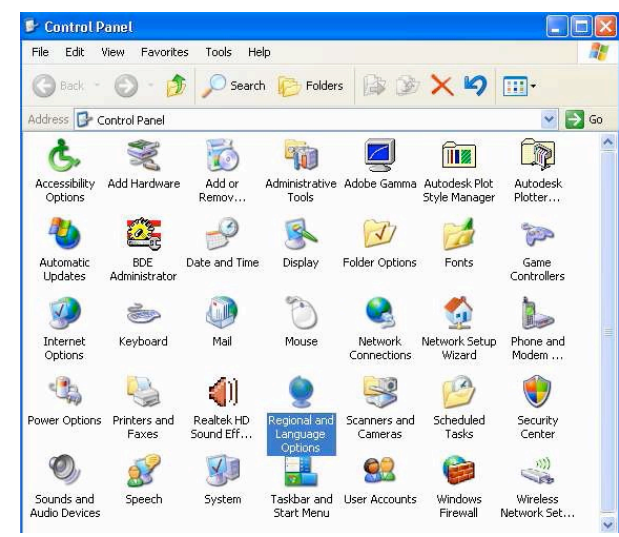

Gambar 5. Control Panel

\section{E. Barcode}

Barcode merupakan instrumen yang bekerja berdasarkan asas kerja digital. Pada konsep digital, hanya ada 2 sinyal data yang dikenal dan bersifat boolean, yaitu 0 atau 1 . Ada arus listrik atau tidak ada (dengan besaran tegangan tertentu, misalnya 5 volt dan 0 volt). Barcode menerapkannya pada batang-batang baris yang terdiri dari warna hitam dan putih. Warna hitam mewakili bilangan 1 dan warna putih mewakili bilangan 0 .

Masing-masing batang pada barcode memiliki ketebalan yang berbeda. Ketebalan inilah yang akan diterjemahkan pada suatu nilai. Demikian karena ketebalan batang barcode menentukan waktu lintasan bagi titik sinar pembaca yang dipancarkan oleh alat pembaca. Oleh karena itu, batangbatang barcode harus dibuat demikian sehingga memiliki kontras yang tinggi terhadap bagian celah antara (yang menentukan cahaya). Sisi-sisi batang barcode harus tegak dan lurus, serta tidak ada lubang atau noda titik ditengah permukaannya. Sementara itu, ukuran titik sinar pembaca juga tidak boleh melebihi celah antara batang barcode. Code 128 adalah barcode dengan kerapatan tinggi, Barcode code 128 ideal untuk aplikasi seperti shipping and warehouse management (pangaturan maskapai pelayaran dan pengelolaan gudang). dapat mengkodekan keseluruhan simbol ASCII (128 karakter) dalam luasan yang paling minim dibandingkan dengan barcode jenis lain, hal ini disebabkan karena code 128 menggunakan 4 ketebalan elemen (bar atau spasi) yang berbeda (jenis yang lain kebanyakan menggunakan 2 ketebalan elemen yang berbeda). Setiap karakter pada code 128 dikodekan oleh 3 bar dan 3 spasi (atau 6 elemen) dengan ketebalan masing-masing elemen 1 sampai 4 kali ketebalan minimum (module), jika dihitung dengan satuan module maka tiap karakter code 128 terdiri dari 11 module kecuali untuk stop character yang terdiri dari 4 bar 3 spasi (13 module). Jumlah total module untuk bar selalu genap sedangkan untuk spasi selalu ganjil, selain itu code 128 memiliki 3 start character yang berbeda sehingga code 128 memiliki 3 sub set karakter yang bersesuaian dengan start characternya. Code 128 memiliki fitur untuk dapat bergeser dari subset yang satu ke sub set yang lainnya dengan menggunakan Karakter CODE dan SHIFT, CODE X menyebabkan seluruh message bergeser menjadi sub set $\mathrm{X}$ (misalnya CODE A pada sub set B membuat message menjadi sub set A), sedangkan SHIFT menyebabkan satu karakter didepannya bergeser sub set (ini hanya berlaku untuk sub set A ke sub set B atau sebaliknya).

ITF barcode hanya dapat mengkodekan angka saja dansering digunakan pada produk-produk yang memiliki kemasandengan permukaan yang tidak rata (misalnya corugated box),hal ini disebabkan struktur dan cara pengkodean ITF yang unik.

Setiap karakter pada ITF barcode dikodekan dengan 5elemen yaitu 2 elemen tebal dan 3 elemen sempit, dimanaelemen tebal mewakili digit biner 1 sedangkan elemen tipismewakili digit biner 0 dengan perbandingan ketebalan antaraelemen tebal dengan elemen tipis $2: 1 \mathrm{~s} / \mathrm{d} 3: 1$.

Keunikan dari ITF adalah pengkodean karakternyaapakah menggunakan bar ataukah menggunakan spasitergantung pada posisi sesuai dengan namanya interleaved, ataulebih jelasnya sebagai berikut : Karakter pertama dikodekanmenggunakan bar setelah start character, sedangkan karakterkedua dikodekan menggunakan spasi secara interleaved padakarakter pertama, karena sifat berpasang-pasangan itulahpanjang message termasuk check character haruslah genap jikajumlahnya ganjil maka harus ditambahkan karakter 0 pada awalmessage, sebelum diillustrasikan contoh ITF barcode, akanlebih jelas jika Anda melihat tabel karater set ITF di bawah ini.

\begin{tabular}{|c|c|c|}
\hline $\begin{array}{l}\text { Karakter } \\
\text { ASCII }\end{array}$ & $\begin{array}{c}\text { Kode } \\
\text { Biner }\end{array}$ & $\begin{array}{r}\text { Nilai } \\
\text { karakter }\end{array}$ \\
\hline 1 & 10001 & 1 \\
\hline 2 & 01001 & 2 \\
\hline 3 & 11000 & 3 \\
\hline 4 & 00101 & 4 \\
\hline 5 & 10100 & 5 \\
\hline 6 & 01100 & 6 \\
\hline 7 & 00011 & 7 \\
\hline 8 & 10010 & 8 \\
\hline 9 & 01010 & 9 \\
\hline 0 & 00110 & 0 \\
\hline Start & $0000^{*}$ & \\
\hline Stop & $100^{*}$ & \\
\hline
\end{tabular}

Start dan Stop character tidak dikodekan secara interleavedtetapi bergantian bar dan spasi 


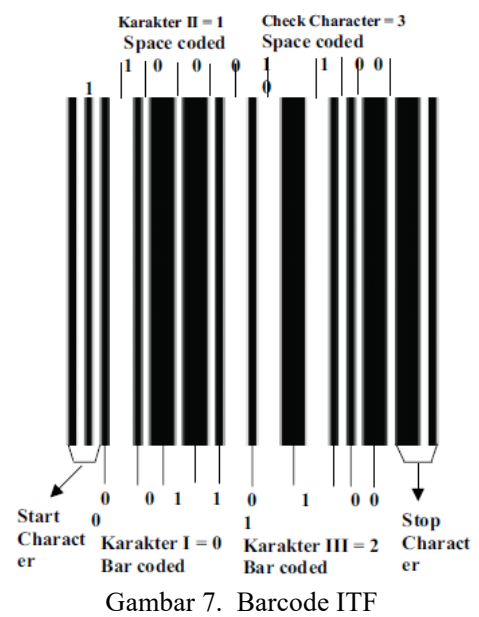

Contoh perhitungan check character ITF barcode adalah sebagai berikut :
Message
$: 2632534$
Karakter
:2632534
Posisi
: EOEOEOE ( $\mathrm{k}$ a r a k t e r paling kanan dimulai sebagaiE)

Jumlah dari posisi odd $: 6+2+3=11$

Jumlah dari posisi even : $2+3+5+4=14$

Jumlah odd $\mathrm{x} 3 \quad: 14 \times 3=42$

Step $6+$ step $7 \quad: 11+42=53$

Angka terkecil untuk menjadi kelipatan 10:7

Check character $\quad: 7$

Tag to be encoded : $: 26325347$

Jumlah keseluruhan karakter plus check character

genapsehingga tidak diperlukan leading zero.

Kode dalam barcode tidak dapat dibaca secara langsung oleh komputer, sehingga data barcode tersebut harus dikodekan terlebih dahulu menjadi format data agar dapat dibaca oleh komputer. Perangkat yang dapat membaca pengkodean barcode menjadi format data tersebut dikenal sebagai barcode scanner atau barcode reader.

Sebuah barcode reader terdiri dari scanner, decoder dan kabel interface ke komputer. Barcode scanner mendeteksi kode-kode dalam barcode yang berupa susunan garis dan spasi, kemudian mengirimkannya ke decoder. Decoder akan menterjemahkan garis dan spasi pada output yang kemudian akan ditransmisikan ke komputer dengan format data yang sesuai dan dapat dibaca oleh komputer. Saat scanning barcode, data akan dikirim ke komputer seperti penekanan pada keyboard.

2.2.3.1 Barcode scanner mempunyai berbagai tipe, antara lain :

Led (Pen Type Reader)

CCD (Charge Coupled Device)

Laser, dan Camera Barcode Scanner

CCD adalah salah satu jenis barcode scanner yang sering digunakan secara luas. CCD merupakan satu deret photocell dalam satu chip semikonduktor, tidak seperti pada satu photocell yang hanya dapat melihat satu bagian barcode. CCD juga dapat mengenali dan membaca keseluruhan bagian barcode dalam satu kali scanning. Sumber cahaya barcode dihasilkan oleh LED (Light Emitting Diode) yang terdapat pada bagian kepala barcode scanner. Sedangkan lebar sensor CCD digunakan untuk menentukan lebar maksimum dari barcode yang masih dapat dibaca. Jika lebar barcode melebihi lebar sensor, maka sensor tidak dapat membaca barcode tersebut.

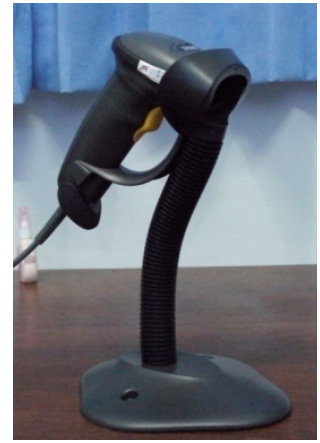

Gambar 8. Model CCD Barcode Scanner

\section{Metode Penelitian}

Pada Sistem informasi peminjaman dan perawatan intrumentasi di Laboratorium Telekomunikasi Politeknik Negeri Malang merupakan suatu aplikasi pelayanan peminjaman instrumentasi. Aplikasi ini akan memudahkan peminjam dibanding secara manual. Dalam sistem ini peminjam hanya menyerahkan KTM yang sudah ada kode barcode dan mengambil alat instrumen yang sudah diberi Idbarcode. Pembuatan sistem ini menggunakan bahasa pemrograman ms access 2003.

\section{A. Diagram Blok Sistem}

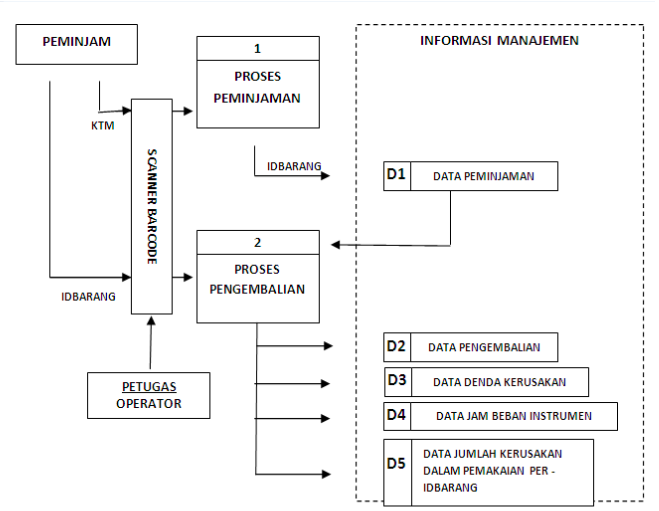

Gambar 9. Diagram Blok Sistem

Lebih Peminjam disini adalah mahasiswa, dosen, dan karyawan administrasi, yang sudah terdaftar sebagai anggota. Untuk mahasiswa IDBracode berdasarkan NIM yang ada di KTM, dosen dan karyawan berdasarkan NIP. Peminjam hanya menyerahkan KTM / IDBarcode dan diserahkan ke petugas untuk proses scanning dengan menggunakan barcode scanner, lalu dipersilahkan meminjam barang instrumen berlabel barcode, petugas akan men scan barang yang dipinjam berdasarkan jam peminjaman.

Untuk pengembalian ada dua cara otomatis dan manual, untuk otomatis petugas hanya menscan label barcode IDBarang, otomatis mengisi jam pengembalian. Secara 
manual petugas hanya meng klik kolom jam kembali. Aplikasi ini secara keseluruhan terbagi menjadi dua bagian yaitu, aplikasi untuk administrator dan petugas. Administrator dapat menggunakan semua fasilitas yang tersedia yaitu, menambah dan mengedit data instrumentasi , mahasiswa, ganti password, user akses, peminjaman dan pengembalian instrumen serta fasilitas report simulasi dan data. Untuk petugas hanya dapat menggunakan beberapa fasilitas antara lain, simulasi peminjaman, pengembalian, tanggungan denda kerusakan serta fasilitas report simulasi dan data. Dalam merencanakan pembuatan software aplikasi ini, langkah pertama yang dapat dilakukan adalah pembuatan flowchart dari keseluruhan sistem sehingga dapat lebih mudah dalam merancang suatu program.

\section{B. Rancangan Alur Proses}

Proses ujicoba Sistem Informasi Peminjaman Dan Perawatan Istrumentasi Laboratorium Telekomunikasi Politeknik Negeri Malang ini bisa dilakukan dalam dua tahap. Tahap pertama bisa dilakukan dengan sebuah simulasi dalam skala kecil untuk melihat sejauh mana efektifitasdan efisiensi dari sistem yang dikembangkan.Tahap kedua merupakan uji coba yang dilakukan pada lingkungan yang sebenarnya, yaitu peminjaman dan pengembalian di ruang instrumentasi teknik elektronika. Tipe barcode yang digunakan dalam tugas akhir ini adalah code-128B. Perencanaan pembuatan barcode ini menggunakan module yaitu program yang ditulis dengan acces Basic. Dengan fasilitas ini, pembuatan barcode menjadi lebih cepat dan mudah.

\section{Perencanaan Aplikasi}

Aplikasi ini secara keseluruhan terbagi menjadi dua bagian yaitu, aplikasi untuk administrator dan petugas. Administrator dapat menggunakan semua fasilitas yang tersedia yaitu, menambah dan mengedit data instrumentasi , mahasiswa, ganti password, user akses, peminjaman dan pengembalian instrumen serta fasilitas report simulasi dan data. Untuk petugas hanya dapat menggunakan beberapa fasilitas antara lain, simulasi peminjaman, pengembalian, tanggungan denda kerusakan serta fasilitas report simulasi dan data.

Dalam merencanakan pembuatan software aplikasi ini, langkah pertama yang dapat dilakukan adalah pembuatan flowchart dari keseluruhan sistem sehingga dapat lebih mudah dalam merancang suatu program. Proses ujicoba Sistem Informasi Peminjaman Dan Perawatan Instrumentasi Laboratorium Telekomunikasi Politeknik Negeri Malangini bisa dilakukan dalam dua tahap. Tahap pertama bisadilakukan dengan sebuah simulasi dalam skala kecil untuk melihat sejauh mana efektifitasdan efisiensi dari sistem yang dikembangkan. Tahap kedua merupakan uji coba yang dilakukan pada lingkungan yangsebenarnya, yaitu peminjaman dan pengembalian di ruang instrumentasi

\section{Analisis Hasil Uji Coba}

Setelah percobaan selesai dilakukan, akan dilakukan analisa terhadap hasil ujicoba terhadapsistem. Proses analisa ini meliputi beberapa hal, yang disesuaikandengan karakteristik dari sistem informasi. Hal yang bisa dianalisa.Yaitu, kinerja yang dinilai adalah response time yang diterima oleh pemakai. Response time di sinidihitung mulai dari saat pemakai memasukkan data sampai pada saat pemakai menerimadokumen yang diinginkan dari system.

\section{E. Effesiensi waktu}

Efisiensi waktu disinidihitung mulai dari saat peminjaman dan pengembalian, Tabel 1 merupakan daftar peminjaman alat yang akan dijadikan data perbandingan, untuk pengecekan waktu menggunakan stopwatch di fasilitas.

\begin{tabular}{|l|l|l|}
\hline No. & Nama Barang & Jumlah \\
\hline 1 & Ossiloscope & 1 \\
\hline 2 & Multimeter & 1 \\
\hline 3 & Kabel AC & 1 \\
\hline 4 & BNC Aligator & 2 \\
\hline
\end{tabular}

Tabel 2. Daftar peminjaman alat

Proses peminjaman secara manual ditunjukkan pada gambar 8, yaitu:

[1] Pengajar memberikan konfirmasi sebelumnya kepada teknisi sebelum pelaksanaan praktikum, berupa alat apa yang akan digunakan untuk praktikum.

[2] Pengajar mengintruksikan kepada mahasiswa untuk meminjam.

[3] Mahasiswa mengambil form peminjaman di petugas, mahasiswa mengisi form peminjaman berdasarkan konfirmasi dari pengajar kepada teknisi sesuai dengan job sit.

[4] Pengisian form tidak boleh diwakilkan pada kelompok lain, dan harus meninggalkan KTM sebagai bukti identitas peminjam.

[5] Teknisi mengecek ulang form peminjaman alat yang udah diisi oleh mahasiswa guna mencocokkan barang yang dipinjam.

[6] Mahasiswa mengecek ulang alat yang sudah dicek oleh teknisi sebelum digunakan untuk praktikum.

[7] Pada waktu pelaksanaan praktikum, mahasiswa diberi tenggang waktu 15 menit dari waktu peminjaman awal untuk menukarkan alat yg trouble. Bila sudah berjalan 15 menit maka alat itu dianggap ready semua dan tidak dilayani untuk ditukar kembali, kecuali pengajar konfirmasi kembali kepada teknisi.

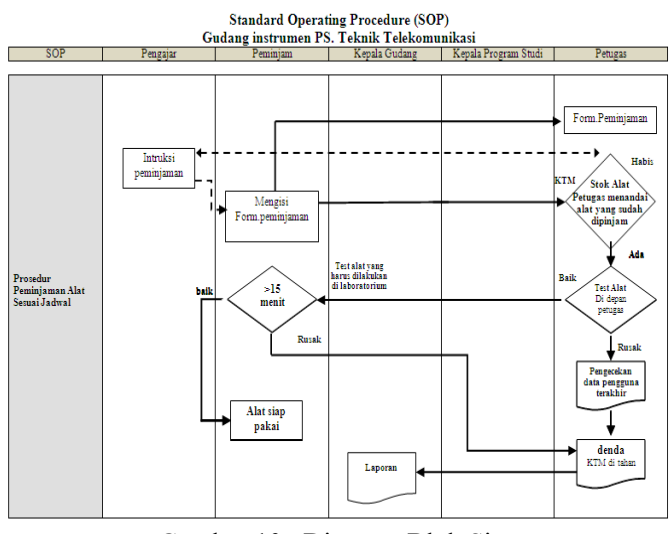

Gambar 10. Diagram Blok Sistem

Berdasarkan peminjaman manual dan software diatas maka hasil perbandingan dapat dibuat daftar table 2 dibawah ini. 


\begin{tabular}{|c|c|c|c|c|}
\hline $\begin{array}{c}\text { No } \\
\text {. }\end{array}$ & lama & manual & software & keterangan \\
\hline 1 & $\begin{array}{l}\text { Waktu } \\
\text { peminjaman }\end{array}$ & $\begin{array}{l} \pm 2 \text { menit } \\
25 \text { detik }\end{array}$ & \pm 1 menit & $\begin{array}{l}\text { Dilakukan } \\
\text { hanya satu } \\
\text { kelompok } \\
\text { mahasiswa } \\
\text { (satu kelas } \\
\text { biasanya } \\
\text { dibagi enam } \\
\text { kelompok) }\end{array}$ \\
\hline 2 & $\begin{array}{l}\text { Waktu } \\
\text { pengembalia } \\
\mathrm{n}\end{array}$ & $\begin{array}{l} \pm 30 \\
\text { detik }\end{array}$ & \pm 20 detik & $\begin{array}{l}\text { Dilakukan } \\
\text { hanya satu } \\
\text { kelompok }\end{array}$ \\
\hline 3 & $\begin{array}{l}\text { Pencarian di } \\
\text { histori } \\
\text { peminjaman }\end{array}$ & $\begin{array}{ll} \pm & 3 \\
\text { menit }\end{array}$ & \pm 7 detik & $\begin{array}{l}\text { Kerusakan } \\
\text { oleh } \\
\text { peminjam } \\
\text { terakhir } \\
\text { (pencarian } \\
\text { kode alat) }\end{array}$ \\
\hline 4 & ketelitian & $\begin{array}{l}6(12 \\
\text { kode } \\
\text { yang } \\
\text { harus } \\
\text { diisi })\end{array}$ & $\begin{array}{l}\text { semua (30 } \\
\text { kode alat) }\end{array}$ & $\begin{array}{l}\text { Dalam hal } \\
\text { penulisan } \\
\text { kode } \\
\text { alat(diambil } \\
\text { dari enam } \\
\text { kelompok) }\end{array}$ \\
\hline 5 & Biaya & $\begin{array}{l}\text { Selalu } \\
\text { membut } \\
\text { uhkan }\end{array}$ & $\begin{array}{l}\text { Bila } \\
\text { diperlukan }\end{array}$ & Kertas \\
\hline
\end{tabular}

Tabel 3. Daftar Konversi waktu peminjaman

\section{Kesimpulan}

Pada Dari hasil perancangan, pembuatan dan pengujian alat "Sistem Informasi Peminjaman Dan Perawatan Instrumentasi Laboratorium Telekomunikasi Politeknik Negeri Malang", maka dapat diambil beberapa kesimpulan sebagai berikut : Scanner barcode CCD digunakan untuk mengkodekan data barcode yang berupa wide dan narrow bar ke format data yang dapat dibaca oleh PC (komputer).

Dengan penggunaan software microsoft access 2003 dapat dibangun suatu sistem aplikasi peminjaman instrumentasi di laboratorium secara otomatis untuk mengatasi permasalahan efektifitas dalam sistem pelayanan.

Dengan efisiennya waktu peminjaman dapat digunakan untuk kegiatan lainnya.

\section{Daftar Pustaka}

[8] Anonim (2010) manajemen perawatan teori (http://www.scribd.com) Diambil 3 September 2012

[9] Anonim (2010). Manajemen pemeliharaan (http://maintenancegroup.blogspot.com) Diambil 3 September 2012

[10] Anonim (2012). barcodes_in_access (http://www.dlsoft.com) htm Diambil 9 agustus 2012

[11] Anonim (2012). Basis data (http://id.wikipedia.org) Diambil 1 agustus 2012

[12] Anonim (2012). Microsoft Access(http://en.wikipedia.org) Diambil 9 agustus 2012

[13] Erup (2010). DataBase (lecturer.eepis-its.edu) Diambil 1 agustus 2012

[14] John S. Dranchak , Joseph R. Lacroce,1995, "membuat aplikasi menggunakan access 2 (menggunakan pemrograman point ang klik)", Jakarta: Elex Media Komputindo.
[15] LPKBM MADCOMS,2003 'Microsoft Access 97', Madiun: LPKBM MADCOMS.

[16] Muhammad Ghazali (2008). Perancangan Database (http://muhammadghazali. wordpress.com) Diambil 9 agustus 2012 